\title{
БЕЗБОРОДЬКО О.А.
}

https://orcid.org/0000-0002-7031-4078

Національна музична академія України імені П. І. Чайковського, Київ, Україна olegbezborodko@gmail.com

\section{ВЗАЕМОДІЯ КОМПОЗИТОРСЬКИХ І ВИКОНАВСЬКИХ ЗАСОБІВ ВИРАЗНОСТІ В ДРУГІЙ СОНАТІ-БАЛАДІ БОРИСА ЛЯТОШИНСЬКОГО}

Проаналізовано взаємодію композиторських і виконавських засобів виразності в Другій сонаті-баладі Бориса Лятошинського. Окреслено основні композиційні особливості даного твору, його стильову специфіку та образний зміст. Розглянуто роль виконавських засобів виразності у формотворенні та стилеутворенні даної п'єси. Зазначено, що від інтерпретатора очікується визначення темпового плану твору, значна міра метроритмічної свободи, застосування динамічних, педальних і аплікатурних прийомів для виявлення звукових ідей композитора.

Ключові слова: музичні засоби виразності, композиторські засоби виразності, виконавські засоби виразності, інтерпретація, фортепіанна творчість Б. Лятошинського.

Постановка проблеми. Характерний для академічної музики останніх двох століть поділ сфер композиторської та виконавської творчості спричинив виокремлення галузі теоретичних досліджень, пов'язаних з питаннями інтерпретації. Акцент теорії інтерпретації на самостійності виконавської версії музичного твору зумовлює розрізнення понять «твір композитора» $\mathrm{i}$ «твір виконавця» $[8,31]$. У той же час дискусійним залишається питання про розмежування композиторських $\mathrm{i}$ виконавських засобів виразності. Розуміння діалектики взаємодії композиторських і виконавських засобів виразності $€$ необхідною умовою адекватної інтерпретації, особливо творів експресіоністичного напряму, яскравим прикладом якого в українській музиці є Друга соната-балада Бориса Лятошинського.

Аналіз останніх досліджень і публікацій. М. Давидов характеризує композиторські та виконавські засоби виразності як, відповідно, стабільні та мобільні. Їх художньо доцільне співвідношення розглядається вченим як «основа професійної інтерпретації музичного твору» [1]. Багато дослідників відзначають неоднозначність і умовність загальноприйнятого поділу художніх засобів музики на виконавські та композиторські. Так, О. Сокол уважає, що «виконавські засоби музичної виразності $<\ldots>\epsilon$ в переважній більшості випадків також і композиторськими» $[12,7]$. Відзначаючи ілюзорну ясність уживаного розмежування художніх засобів музики на композиторські та виконавські, А. Малінковська, однак, стверджує його неможливість «з точки зору формозмістовної єдності, цілісності художнього організму, яким є музичний твір» [6, 24-25]. Відмічена О. Тарасовою безпрецедентна актуалізація «вторинних» виконавських засобів виразності в музичному мистецтві XX століття, разом 3 їх виходом «на концептуальний та композиційний рівні музичного твору» $[16,124]$, зумовлює актуальність застосування даного дослідницького аспекту до вивчення творів корифея української музики XX століття Б. Лятошинського. Ана- 
лізу ладогармонічних, інтонаційних, стильових, жанрових характеристик творчості композитора 1920-х років присвячено наукові розвідки В. Кліна [3], О. Марценківської [7], О. Підсухи [9], І. Пясковського [10], В. Самохвалова [11], Є. Харченко [16], І. Царевич [17]. У той же час ранні твори Б. Лятошинського, зокрема Друга соната-балада, залишаються мало дослідженими з точки зору теорії виконавства.

Мета статті полягає у висвітленні взаємодії композиторських і виконавських засобів виразності в Другій сонаті-баладі Б. Лятошинського, що має сприяти виробленню адекватної та переконливої інтерпретації цього визначного твору української фортепіанної музики.

Виклад основного матеріалу. Другу сонату-баладу ор. 18 було створено Б. Лятошинським у 1925 році та присвячено російському композитору М. Мясковському. Цю присвяту учень Б. Лятошинського та перший дослідник його творчості I. Белза пояснює «щирою творчою дружбою, що протягом багатьох років зв’язувала двох композиторів» $[1,5]$. Уперше твір було виконано піаністкою В. СтешенкоКуфтіною ${ }^{1}$, якій роком раніше композитор присвятив свою Першу фортепіанну сонату ор. 13. Разом із циклом «Відображення» ор. 16 ці твори є центральними для другого (за В. Самохваловим) періоду творчості композитора (з ор. 5 по ор. 26), в якому, на думку вченого, «домінують експресивні, динамічні образи» $[11,23]$. Спільні композиційно-структурні та стильові риси дозволяють О. Марценківській об'єднувати ці твори в «цілісну умовну макрокомпозицію» $[7,143]$, а В. Клін указує на велику кількість тематичних та фактурних зв'язків між ними $[3,51]$.

Характерною для почерку Б. Лятошинського у 20-ті роки Є. Харченко вважає «експресивність музичного вислову, через яку проглядає трагічність світовідчуття. Вона межує з особливим ліризмом, глибоко індивідуальним відчуттям музичності як способу екзистенційного утвердження себе у світі, оригінально втіленим у стильовому контексті музичної поетики композитора» $[16,69]$. Певного проникнення в музичну поетику Б. Лятошинського часу створення перших двох сонат та циклу «Вiдображення» ми можемо досягти через звернення до нещодавно опублікованих сторінок щоденника В. Стешенко-Куфтіної - людини, з якою, за думкою дослідниці apхіву піаністки О. Степанюк, композитор «мав тісний духовний зв'язок і спорідненість» $[13,469]$. Перша й улюблена інтерпретаторка творів Б. Лятошинського, чия виконавська манера мала великий вплив на формування індивідуального стилю фортепіанних творів композитора, В. Стешенко-Куфтіна так описує авторський задум Першої сонати: «Він написав сонату, яка вся насичена одним образом жінки, який він побачив в одному із старовинних альбомів. Друга частина - $\epsilon$ поява цього образу, що далі бореться з фатумом, який розбиває цю жінку-марення, і все застигає в тихому несамовитому крику. Портрет цієї жінки простий, у середньовічному стилі, у темно-зеленій сукні. От і все. Просте, вдумливе обличчя, і дуже жіноче» [14, 345-346].

Глибокий символізм фортепіанних творів Б. Лятошинського 20-х років, в яких крізь призму самобутнього лірико-трагедійного світовідчуття своєрідно відбиваються пізньоромантичні експресіоністичні тенденції, поширені в музичному мистецтві початку XX століття ${ }^{2}$, вимагає від виконавця надвисокого рівню емоційної напру-

${ }^{1}$ Валентина Костянтинівна Стешенко-Куфтіна (1904-1953) закінчила Київську консерваторію за класом фортепіано Ф. М. Блуменфельда, працювала у Київській державній музичній професійній школі у 20-ті роки, у 30-50-ті роки викладала спеціальне фортепіано у Тбіліській консерваторії. Окрім викладацької та виконавської діяльності займалася збиранням і вивченням музичного фольклору.

${ }^{2}$ Як зазначає О. Підсуха, стильова система творів Б. Лятошинського 20-х років «наче балансує на межі пізньоромантичного, символістського, експресіоністського стильового контінууму. В 
ги в переживанні музичної тканини, інтерпретації скоріше суб'єктивного, ніж об'єктивного спрямування ${ }^{1}$. Важливим стильовим орієнтиром може бути творчість О. Скрябіна, вплив якої на образність, гармонію та композиційну будову творів Б. Лятошинського зазначався багатьма дослідниками [3; 7; 10; 11; 17], та музика А. Шенберга і А. Берга, прямий вплив якої на формування самобутнього стилю українського композитора, активного діяча Асоціації сучасної музики, що пропагувала нововіденців, «неможна недооцінювати» $[9,28]$. У різноманітному музично-стильовому спектрі 20-х років творчість композитора знаходиться на протилежному полюсі по відношенню до неокласичних прагнень I. Стравінського, С. Прокоф'єва, П. Гіндеміта, про що свідчить звуковисотна організація фортепіанних творів Б. Лятошинського, яка намагається вийти за межі тональної системи, їх насичена різними прийомами романтичного піанізму (арпеджіо, мартелято, значна роль не позначеної, проте необхідної педалізації) фактура, а також складний мінливий метроритм і мелодична ламаність. Відповідно й виконання повинно бути далеким від об'єктивної точності неокласичної інтерпретації ${ }^{2}$, воно вимагає імпровізації, романтичного запалу та поривчастості, значної міри конгеніальності інтерпретатора.

Питання про взаємодію композиторських і виконавських засобів виразності гостро постає вже при інтерпретації вступної імперативно-вольової тези, з якої виростає майже вся музична тканина твору (приклад 1).

Б. Лятошинський. Соната-балада № 2, тв. 18, вступ

Приклад 1.

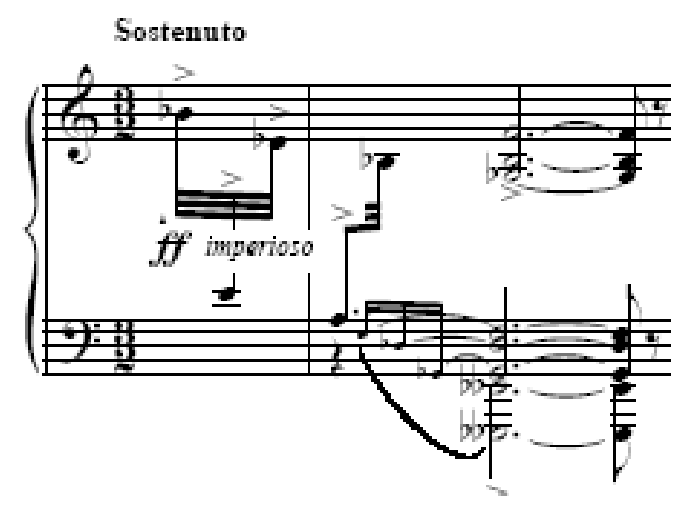

кожному окремому творі переважають чи виступають у рівновазі елементи цих, глибинно і генетично споріднених стильових напрямків» $[9,27]$.

${ }^{1}$ За Н. Корихаловою, антитеза «суб'єктивне - об'єктивне» $\epsilon$ основною для музичновиконавської проблематики $[4,15]$. Дослідниця розрізняє два напрямки у виконавському мистецтві, які сприяли розмежуванню суб'єктивістів і об'єктивістів, - пізньоромантичний і академічний. У першому, на думку вченої, «ознаки романтичного виконавства (перебільшена виразність, “особистісність” висловлювання, загострення темпових характеристик, контрастність динаміки, зацікавлення барвистістю звучання) отримують гіпертрофоване вираження. Для другого характерні стриманість, строгість, іноді сухуватість, почуття міри, увага до архітектоніки твору і одночасно до деталі, бережне ставлення до авторського тексту» $[4,21]$.

2 До принципів «неокласичної інтерпретації» ісландський композитор і диригент Йоун Лейфс відносить чітку зміну форте і піано, живе стакато, вміння передати поліфонічність тканини, суворе, невібратне звучання, яскраві акценти, чіткий ритм» [цит. за: 4, 33]. Недоліками гри вважаються надмірне rubato, чуттєві crescendi i diminuendi.

112 ISSN 2522-4190. Науковий вісник Національної музичної академії України імені П. І. Чайковського. 2018. Вип. 122 
В ній ритмічно активна тритоново-секундова послідовність веде до гармонічного комплексу, побудованого на акорді, який став згодом «візитівкою» композитора - великому септакорді у всіляких трансформаціях ${ }^{1}$. Композитор таким чином розташовує звукову тканину відносно тактової риски, що потужний акордовий комплекс припадає на другу чверть першого такту, тобто є синкопою. В кожному з повторень цього мотиву в наступних двох тактах звук фа (мелодична вершина акорду) припадає на слабку долю, що підтверджує принципову для композитора питальність інтонації висхідної квінти, яка веде до цього звуку.

Щоб виявити цю оригінальну та надзвичайно виразну звуко-метроритмічну побудову, піаністу потрібно зіграти акордовий комплекс рухом вгору та мислити його як відображення руху вниз, спрямованого до одиночної ноти ля на першій долі такту. Окрім того, особливу увагу слід приділити виконанню пунктирної 32-ї сі-бемоль у правій руці. 3 одного боку, їі зазначена тривалість і патетичний характер висловлювання допускають мінімальну протяжність цього звуку, з іншого - він має залишатися досить потужним і напруженим. Цього можна досягти зміною пальців 32 на пунктирній ноті та наступному сі-бемолі в акорді на другій чверті такту. Проблему поєднання пунктирного сі-бемолю в правій руці з форшлагом із розкладеного акорду в лівій можна вирішити в два способи: 1) форшлаг починається трохи раніше сі-бемоля в правій руці або одночасно з ним, і це дозволяє зіграти пунктир максимально швидко, однак його виразність і розбірливість буде дещо губитися на тлі розкотистого форшлагу; 2) форшлаг грається пізніше сі-бемоля, при цьому пунктир втрачає трохи в швидкості, але виграє у визначеності звучання. Визнаючи прийнятність обох варіантів, ми віддаємо перевагу другому з них через забезпечення в такому випадку найвищої міри виразності інтонації висхідної квінти, яка відіграє величезну роль в драматургії твору. Вибір другого варіанту вимагає, однак, віртуозного виконання форшлагу і подальшого акорду в лівій руці, а також точного взяття правої педалі на ноту пунктиру, як це показано в Прикладі 2.

Б. Лятошинський. Соната-балада № 2, тв. 18, вступ

Приклад $2^{2}$.



${ }^{1}$ у даному випадку цей комплекс можна трактувати як великий мажорний септакорд у положенні септими від соль-бемоль з додаванням баса мі-дубль-бемоль великою терцією нижче, або як зчеплення двох великих мажорних септакордів від мі-дубль-бемоль (з пропущеною квінтою) та від соль-бемоль.

${ }^{2}$ Аплікатурні та педальні позначення додано автором статті, стрілки вказують на напрям рухів рук піаніста 
Другий головний елемент вступу також складається 3 початкового тритонового мотиву, що втілюється в пульсуючому битті, свого роду idée fixe ${ }^{1}$. На iㅣ напруженому тлі спускається з найвищого регістру інструмента щемлива тема, що будується з інтервалів малої секунди та малої терції та закінчується питальним ходом на квінту вгору так само, як і перший імперативний мотив.

Композитор не дає динамічних указівок щодо виконання цього елементу, крім акцентування кожного pe-дiєзy. Трагічність фатального тритону idée fixe вимагає підкреслення його появи раптовим підвищенням динаміки на арпеджованому акорді, виписаному як форшлаг до ре-дієза - початкової ноти пульсуючого биття. Після того як цей мотив заявив про себе, його можна відвести на другий план задля більшої виразності тремтливої теми другого елемента вступу, але без утрати напруги цього пульсу. Аплікатурно такого ефекту легко досягти через розподілення шістнадцятих між двома руками так, як це графічно запропоновано автором, або зігравши усі 16-ті в другій секстолі правою рукою. Далі права рука має виконувати тему у високому регістрі, а створення пульсу 16-х стає завданням лівої руки піаніста. Перші три, або навіть усі шість 16-х, можуть бути трохи притримані задля більшої виразності, тобто ремарка росо piu тоsso стає дієвою десь на останній чверті цього такту.

Б. Лятошинський. Соната-балада № 2, тв. 18,т. 3

Приклад $3^{2}$.

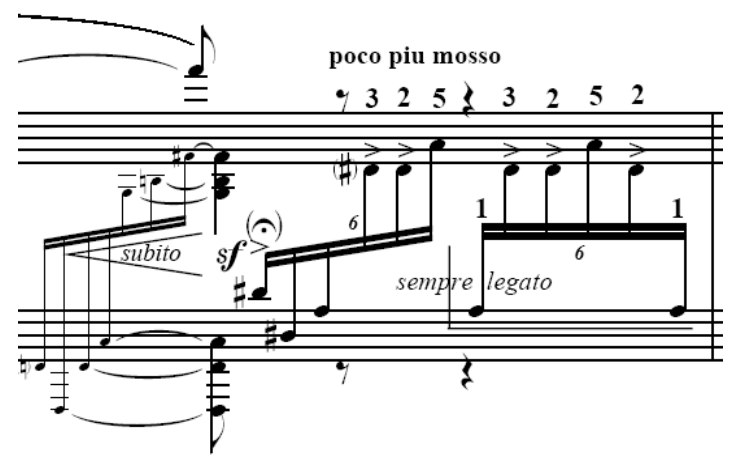

При виконанні другого елемента вступу треба стежити за тим, щоб напружена пульсація в лівій руці не затьмарила собою мелодії у верхньому регістрі інструмента. Незважаючи на те, що пульсація має бути невпинною та ритмічно точною, не варто добиватися ідеального співпадання двох рук, тому що це зашкодить чуттєвості щемливої теми у правій руці, викладення якої повільними (чвертями) тріолями передбачає певну агогічну свободу.

${ }^{1} €$. Харченко зазначає, що інтонація на основі поєднання звуків $м і-м і$-бемоль (ре-дієз) часто у Б. Лятошинського є символом фатальної «образності або потойбічних реалій і вступає у конфліктну взаємодію із авторським мотивом ля-сі-бемоль» $[16,80]$. Дійсно, в темі, що протиставляється пульсації ре-дієза, ми знаходимо сполучення ля й сі-бемоля (ля-дієза) - звукову анаграму композитора, складену з перших літер його імені та прізвища. 3 цих звуків також починається й побічна партія твору. Так само знаходимо, наприклад у заключній темі, анаграму-символ (за С. Харченко) дружини композитора Маргарити Царевич ре - до-дієз.

2 Аплікатурні та динамічні позначення додано автором статті. 
Б. Лятошинський. Соната-балада № 2, тв. 18, т. 4

Приклад 4.

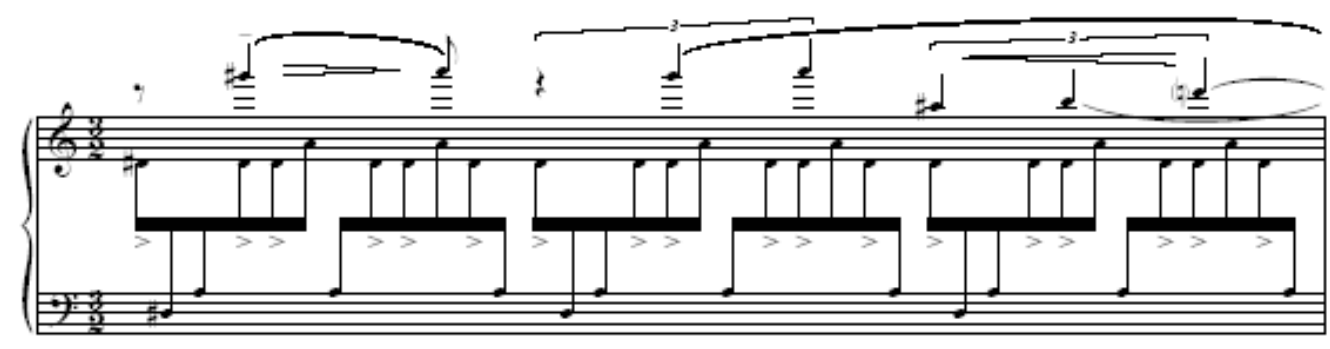

Хоча композитор спеціально не позначає артикуляційні вимоги до виконання головної партії Сонати-балади, їі надзвичайна виразність та інтонаційна напруженість передбачають гнучке й щільне legato. Невеличкі 16-ті паузи у бурхливих гармонічних фігураціях в партії лівої руки мають бути очищеними від педалі, і тоді ці паузи сприятимуть відчуттю легкості та стрімкості руху, його природному «диханню». Вони надають партії лівої руки піаністичної зручності, полегшують використання «запізнілої» педалі та агогічних відхилень. Особлива вправність знадобиться при виконанні уривка головної партії, наведеного в Прикладі 5. Тут, незважаючи на пунктир, все одно слід прагнути до співучості та ліричності інтонації в правій руці. Інакше зайва нервовість рухів у правій руці унеможливить майже миттєве виконання, якого вимагає композитор для октавного форшлагу в лівій. У цьому місці, як і в багатьох інших, вирішення складного технічного завдання лежить у художній площині.

Приклад $5^{1}$.

Б. Лятошинський. Соната-балада № 2, тв. 18, тт..21-22



Незважаючи на динаміку форте і виклад ламаними акордами, в сполучній партії вважаємо доцільним підкреслити їі щемливу сутність - наслідок інтонаційної ідентичності другій темі вступу. Верхній прихований голос в ламаних акордах треба вирізнити і зіграти легато, максимально виразно; гармонічний супровід лівої руки повинен бути досить м'яким з легким підкресленням найнижчих нот (приклад 6).

\footnotetext{
${ }^{1}$ Темпові, педальні й аплікатурні позначення додано автором статті.
} 
Приклад 6.

Б. Лятошинський. Соната-балада № 2, тв. 18, тт.. 40-41

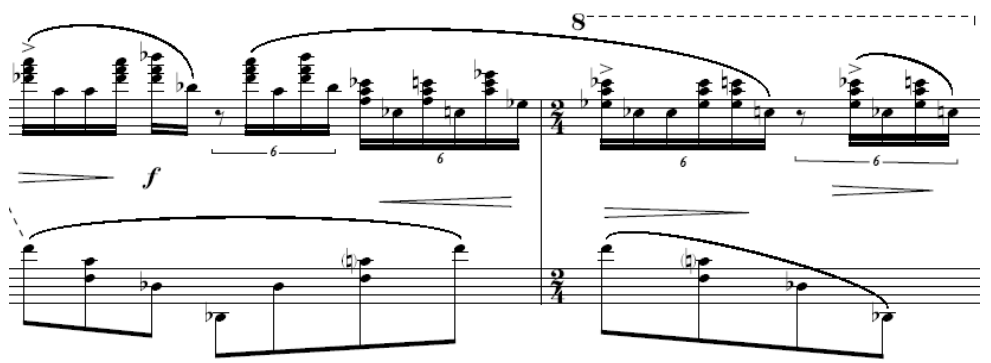

Речитативно-інтимна побічна партія видається нам своєрідним відображенням другого елемента вступу. 3 ним побічну партію зближає ритм та інтервальна будова, заснована на прийомі обернення. Так, низхідна секунда - основний інтервал побічної партії - відповідає висхідній секунді другого елемента вступу, а низхідна велика септима зі вступу перетворюється на висхідні інтервали квінти, великої септими, великої сексти та малої нони (Приклад 7).

Приклад 7.

Б. Лятошинський. Соната-балада № 2, тв. 18, тт..52-56

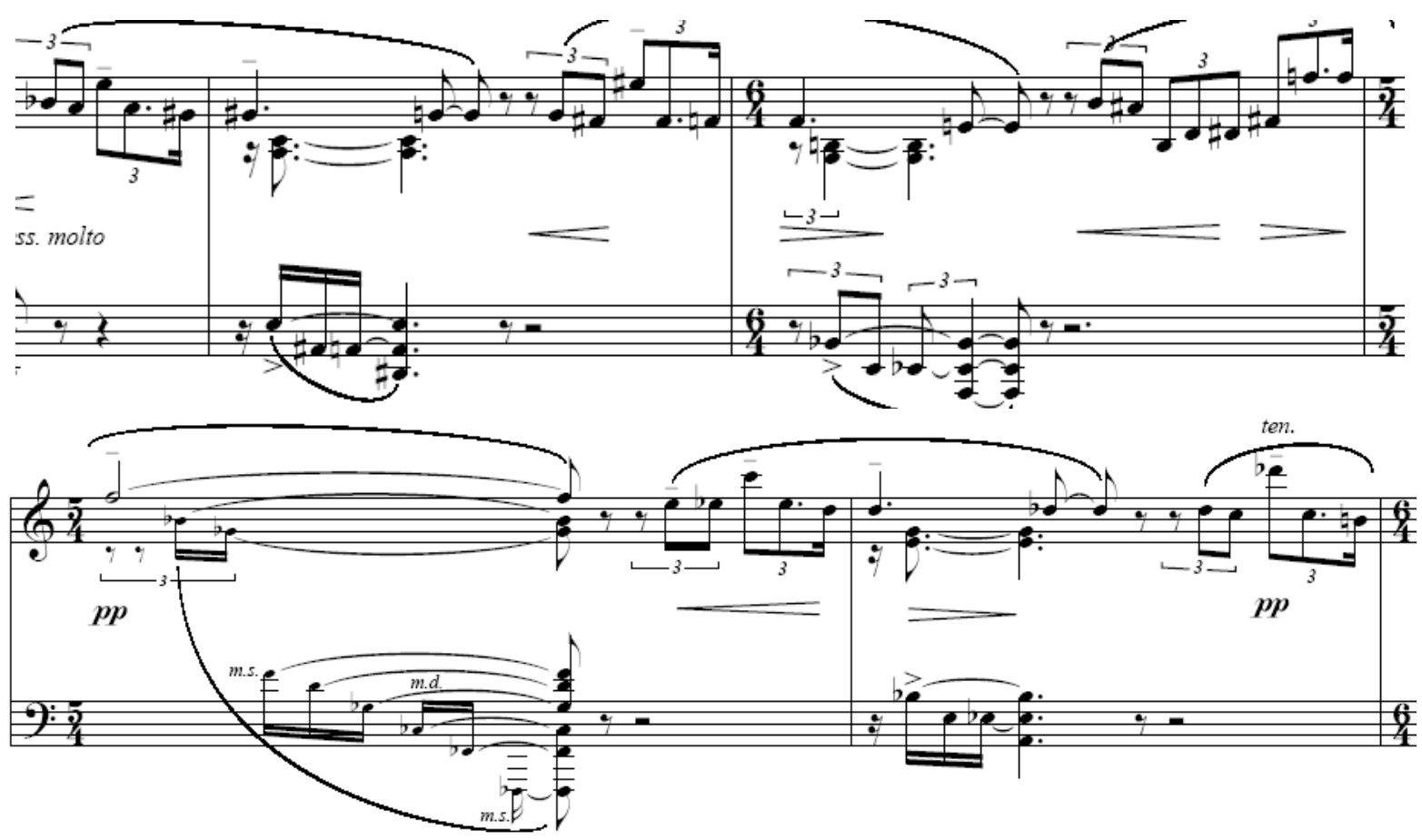

Ще більше ця подібність проявляється в середньому розділі побічної партії (вона написана в простій тричастинній формі). Тут обернена друга тема вступу дається в середньому регістрі інструмента на тлі хитких фігурацій у верхньому регістрі та басових арпеджованих форшлагів, які чітко окреслюють мажорні гармонії (приклад 8). 
Приклад 8.

Б. Лятошинський. Соната-балада № 2, тв. 18, тт..58-60

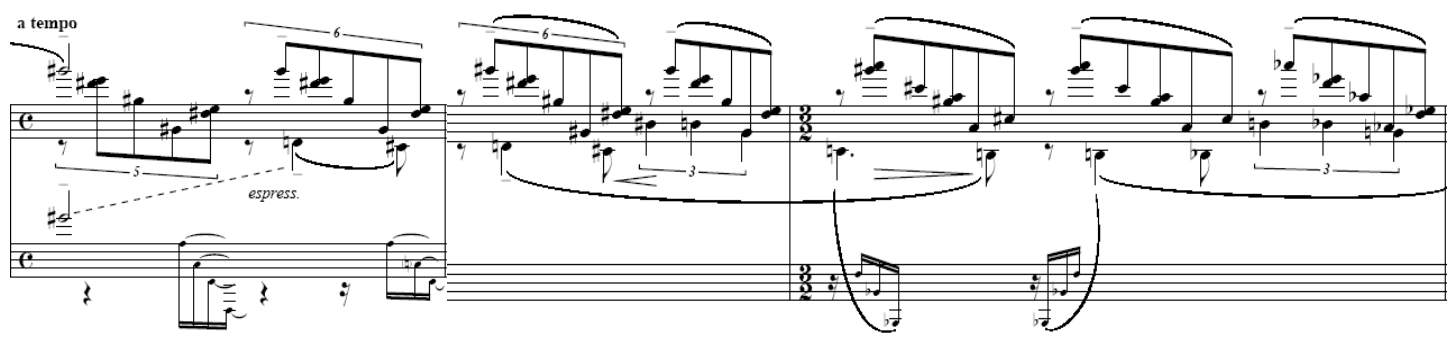

Обернення-відображення щемливої теми з другого елемента вступу здійснюється, таким чином, і на рівнях фактури та гармоніі. Тритонове пульсуюче биття idée fixe перетворюється на хитку, але гармонічно визначену звукову «подушку». На семантичному рівні побічна партія видається «острівцем мрій» посеред бурхливого бентежного напруження всієї сонати, тут примарний образ знаходить на нетривалий час чіткі контури та втілення. Вочевидь, вищенаведене описування В. СтешенкоКуфтіною образного змісту Першої сонати можна екстраполювати і на другий досвід композитора в цьому жанрі. Звернемо також увагу, що перший імперативний елемент вступу також присутній в побічній партіі. Він утворює гармонічно нестійке обрамлення їі крайніх розділів.

Побічна партія вимагає від інтерпретатора значної роботи звукової уяви. Основним інструментом виконавця знову ж $\epsilon$ агогіка, завдяки якій можна добитися речитативної виразності в мелодії, а також динамічного балансу і виокремлення різних звуків та фактурних пластів. Середина побічної партії - місце, де найбільш яскраво проявляються імпресіоністичні пошуки Б. Лятошинського. Зауважимо, що уникнути одноманітності при варіативних повтореннях основного мотиву побічної партії, можна зміною (варіюванням) місцезнаходження кульмінаційного звуку в кожному з таких мотивів.

Суворий характер заключної партії забезпечується композитором унісонним (через октаву) викладом, часовим збільшенням матеріалу головної партії (вдвічі більші тривалості у повільнішому русі) і затаєною динамікою (pp). Заключна партія закінчується ключовою для твору інтонацією висхідної квінти, якій відповідає віддалене звучання в низькому регістрі хору з улюблених композитором великих збільшених і мажорних септакордів (приклад 9).

Б. Лятошинський. Соната-балада № 2, тв. 18, тт.. 68-71

Приклад 9.

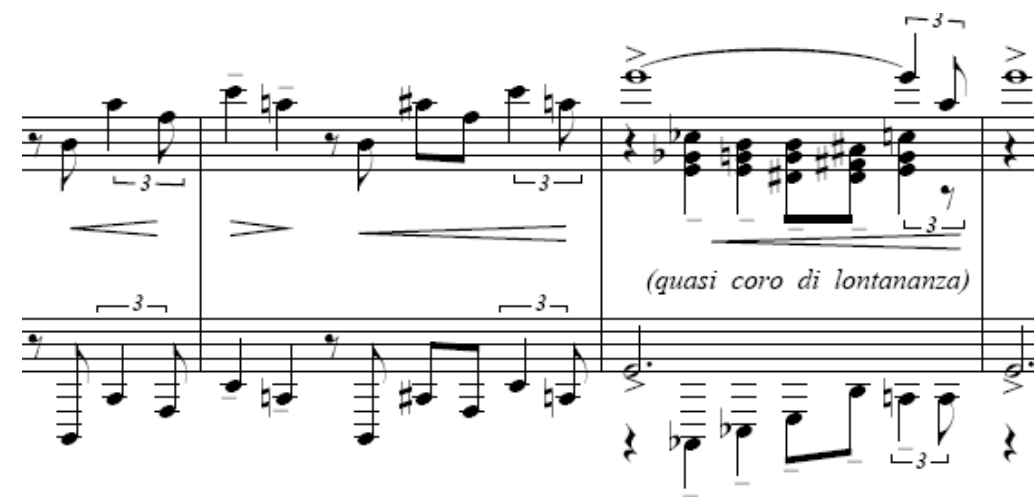


Імітації звучання хору на віддалі вимагає сам автор ремаркою (quasi coro di lontananza). Верхній голос хору також $\epsilon$ виокремленням із мелодичного матеріалу головної партії (їі третій такт). П’ятикратне повторення інтонації висхідної квінти (перші два рази в октавний унісон, далі з додаванням останніх акордів хору) підкреслює ії вершину (звук соль) як тимчасову тональну опору, що підсилює сонатність твору. Зона побічної партії, яка включає в себе і заключну, таким чином, знаходиться в традиційному для сонатного жанру паралельному тональному співвідношенні 3 зоною головної партії: соль - мі.

3 точки зору взаємодії композиторських і виконавських засобів виразності, виконання акордової послідовності, поміченої композитором (quasi coro di lontananza), вимагає надзвичайної майстерності педалізації. Звук соль в обох руках повинен бути зіграний досить голосно, щоб його звучання тривало протягом усього такту. Виконання акордів вимагає постійної підміни педалі, при цьому педаль не можна міняти повністю, щоб не втратити звучання октави соль. Незважаючи на те, що композитор позначає акорди рисками tenuto, ми вважаємо за краще максимально легкий штрих на pianissimo. Враження tenuto, таким чином, буде створюватися педаллю. Для правильного знаходження міри гучності й легкості штриха кожного наступного акорду, після кожної напівзміни педалі піаніст має почути продовжений звук соль. Також можна скористатися середньою педаллю sostenuto, проте слід зважити на те, що композитор, скоріше за все, на неї не розраховував.

Розробка Сонати-балади складається 3 декількох хвиль розвитку. У першій секвенційні повторювання швидких фігур шістнадцятими, побудованими на тритоново-секундовому мотиві з першої тези вступу, перериваються останніми акордами заключної партії. Друга хвиля побудована з двох секвенційних проведень головної партії, розділеної на два елементи, перший з яких проводиться в нижньому регістрі, другий - у верхньому, на фактурному тлі бігу тріолей шістнадцятими, інтерваліка яких близька до побічної партії. Нарешті, третя хвиля розробки є динамізованим викладом головної партії, за фактурою близьким до експозиції, що дозволяє розглядати цю хвилю як хибну репризу. На користь такого погляду говорить і тональність цього епізоду мі-бемоль мінор. Третя хвиля розробки закінчується віртуозним октавним каноном на основі імперативного елемента вступу, секвенційний розвиток якого приводить нас у головну тональність твору мі мінор. Незважаючи на вказівку композитора грати sempre fortissimo, цей віртуозний октавний канон слід виконувати з хвильовою динамікою, тобто бажано періодично знижувати гучність, щоб зберегти відчуття постійного наростання напруження.

Подібне ж розраховування динаміки є запорукою переконливого виконання скороченої репризи, яка являє собою грандіозне проведення в трьохоктавний унісон головної партії, що підтримується мартелятними акордовими «перекатами» мінорних та мажорних великих септакордів. Акордові мартелято, незважаючи на позначку $f f f$, треба починати тихіше, щоб залишити перспективу динамічного розвитку (приклад 8). В перших акордах цих побудов потрібно вирізняти верхні звуки, як складову мелодії, інтонування якої, навіть за умов максимальної гучності, залишається найважливішим завданням піаніста. 
Б. Лятошинський. Соната-балада № 2, тв. 18, тт.. 112-114

Приклад $10^{1}$.

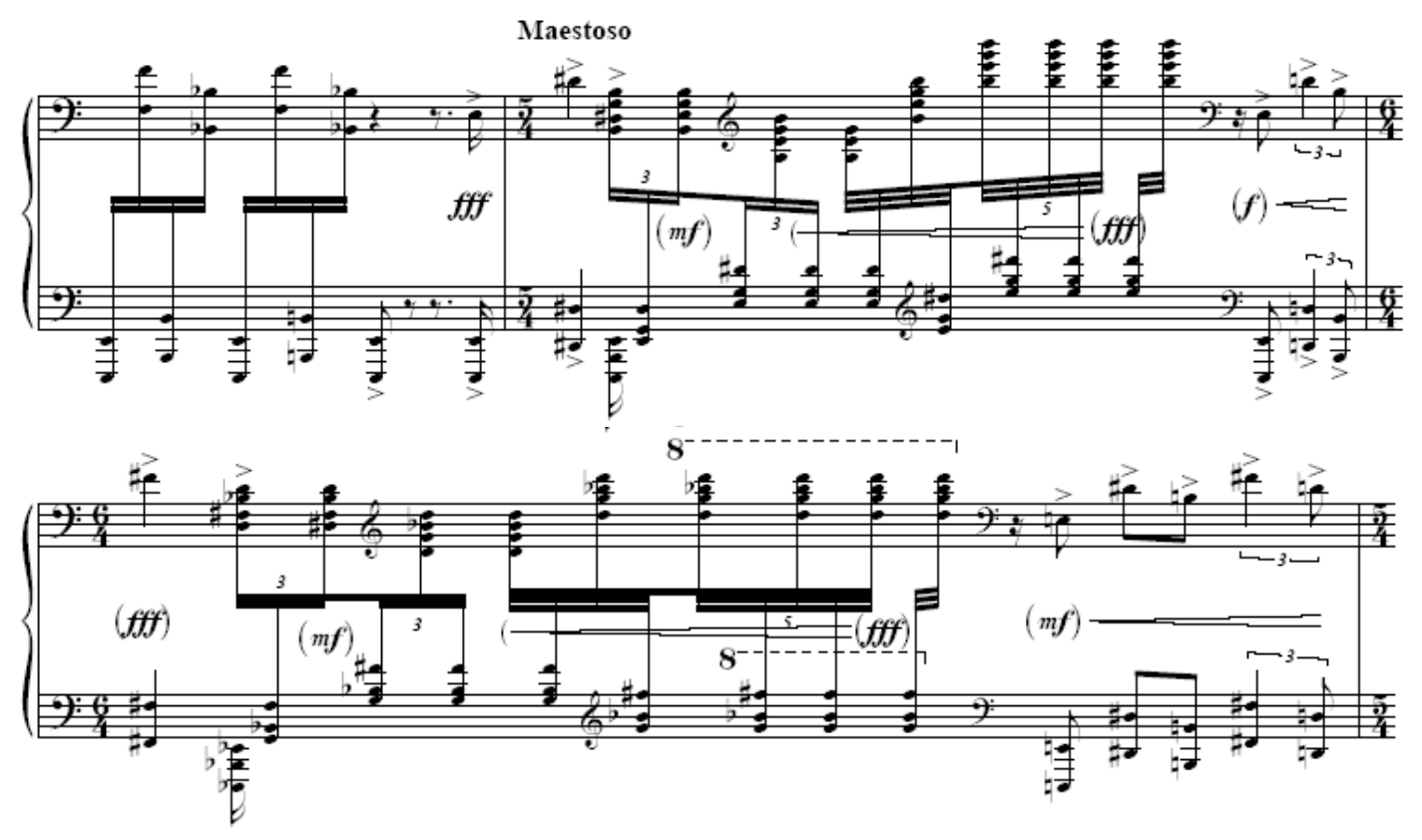

Остання кульмінаційна висхідна квінта ре-ля звуковисотно повторює «запитальну» квінту другого щемливого елемента вступу. Завершує сонату заключна партія, яка звучить як поступове згасання головної теми, основне питання якої (висхідна квінта) так і залишається невирішеним ${ }^{2}$. Це відчуття забезпечується детально виписаним динамічним абрисом теми. Ї̈ї переконливе виконання залежить від міри та якості дотримання збільшеної ферматою паузи перед заключною партією. Емоційність і напруженість цієї паузи вимагають від виконавця навіть певного візуального ефекту, щоб уникнути найменшого відчуття переривання току музики - руки піаніста мають ніби застигнути у повітрі. Особливої уваги варта остання басова нота ля. Обернення питальної квінти у басу є досить простим ефектом, але дуже виразним як акустично, так і семантично. Стверджене «Я» композитора поступається усвідомленню трагічності й незвіданості таємниці буття.

В цілому форма сонати-балади визначається цілісністю, яку забезпечує надзвичайне ритмоінтонаційне зчеплення і взаємопроникнення всіх їі елементів. Слід зазначити, що композитор довго вагався у виборі жанрового визначення твору. Так, у листах до Р. Глієра від 20 червня, 14 листопада, 25 листопада 1925 року та 21 лютого 1926 року Б. Лятошинський говорить про сонату і лише в листі від 21 квітня 1926 р. уперше згадує Сонату-баладу, яку, за його словами, «вирішили все-таки назвати сонатою-баладою, а не просто баладою» [5,87]. Визначення жанру як балади

${ }_{1}^{1}$ Динамічні позначення у дужках додано автором статті.

${ }^{2}$ Низка трансформацій цього основного тематичного зерна сонати, в залежності від інтонаційно-драматургічного контексту його появ, утілює одну з основних, на думку Є. Харченко, ідей творчості Б. Лятошинського - «самоствердження, змужніння творчої особистості, індивідуалістське проголошення свого “Я” на тлі трагічної дійсності» $[16,71]$. Символічним у цьому плані $є$ завершення Сонати-балади на звуці «ля», назва якого становить перші дві літери прізвища композитора. 
безумовно відсилає нас до романтичних фортепіанних балад Ф. Шопена і Ф. Ліста, 3 якими Сонату-баладу Б. Лятошинського зближає вільне трактування сонатної форми, конфліктно-хвильовий тип музичної драматургії, інтонаційна єдність різних, в тому числі й контрастних тематичних побудов. Значне розширення за часом, завдяки уповільненому темпу, зони побічної партії, разом з єдністю та цілісністю розробки і скороченої репризи, дозволяють убачати в цьому творі ознаки складної тричастинної форми. Композитор вельми умовно визначає темпи окремих розділів Сонати-балади. Так, темп вступу позначено як Sostenuto (укр. - стримано), головної партії - Elevato (укр. - піднесено), побічної - Velutato (укр. - оксамитово), початок розробки композитор не вирізняє (!) зміною темпу, проте другу хвилю розробки автор позначає ремаркою Impetuoso (укр. - стрімко). Остання, вказана композитором, зміна темпу припадає на репризу - Maestoso (укр. - велично). Усі ці темпові вказівки насправді визначають лише характер виконання. Саме від виконавця, від вибору ним міри зміни темпу залежить наскільки виявленою буде тричастинність твору, а разом з нею розповідність і картинність, що забезпечують баладну сутність цієї композиції.

Висновки. Друга соната-балада ор. 18 Б. Лятошинського $є$ одним із найзначніших та найскладніших творів української фортепіанної музики. Її адекватна та переконлива інтерпретація неможлива без розуміння взаємодії композиторських i виконавських засобів музичної виразності. Так, від визначення темпового плану твору залежать його образний зміст і сприйняття форми (зокрема, може превалювати трьохчастинність або сонатність), амбівалентність якої закладена вже в назві твору. Як і при виконанні будь-якого великого твору романтичного спрямування, від інтерпретатора очікується значна міра метроритмічної свободи. Разом з тим, експресіоністична стильова спрямованість передбачає точне дотримання багатьох ритмічних фігур (насамперед, нервового, імпульсивного характеру). Необхідне використання особливих динамічних і педальних прийомів для виявлення імпресіоністичних якостей фортепіанного письма Б. Лятошинського, зокрема, це стосується виконання побічної та заключної партій. У той же час найважливішим викликом для піаніста, що береться за інтерпретацію Другої сонати-балади Б. Лятошинського, є неможливість адекватного виконання цієї музики без вирішення завдань вищого художнього порядку, без спроби осмислити звуками найважливіші питання буття, питання домірності людини та іiі долі, митця та суспільства, мистецтва та дійсності. Разом із тим, саме ці виклики роблять геніальний твір класика української музики актуальним і цікавим для нашого сьогодення.

\section{СПИСОК ВИКОРИСТАНИХ ЛІТЕРАТУРИ І ДЖЕРЕЛ}

1. Бэлза И. Фортепианные произведения Лятошинского : вступит. статья. Б. Лятошинский. Сочинения для фортепиано. Москва: Музыка, 1972. С. 5-6.

2. Давыдов Н. Аспекты исполнительского мышления. Таврійські студії. Мистецтвознавство. 2013. № 3. URL: http://nbuv.gov.ua/UJRN/tsm_2013_3_5. (дата звернення: 01.02.2018).

3. Клин В. Фортепианное творчество и художественный стиль Б. Н. Лятошинского. Борис Николаевич Лятошинский : сб. ст. / сост. М. Д. Копица. Киев : Муз. Україна, 1987. C. $42-62$.

4. Корыхалова Н. Интерпретация музыки: теоретические проблемы музыкального исполнительства и критический анализ их разработки в современной буржуазной эстетике. Ленинград: Музыка, 1979. 208 с.

5. Лятошинський Б. Епістолярна спадщина. Т. 1: Борис Лятошинський - Рейнгольд Гліер. Листи (1914-1956) / упор. М. Копиця. Київ, 2002. 768 с. 
6. Малинковская А. Класс основного музыкального инструмента. Искусство фортепианного интонирования. Москва : ВЛАДОС, 2005. $381 \mathrm{c.}$

7. Марценківська О. Загальні тенденції музичного романтизму та їх прояв у фортепіанній творчості Б. Лятошинського // Київське музикознавство. Київ, 2014. Вип. 48. С. 132148.

8. Москаленко В. Лекции по музыкальной интерпретации. Киев, 2012. 272 с.

9. Підсуха О. До проблеми стильових пошуків Б. Лятошинського у 20-ті роки XX ст. в контексті європейських стильових тенденцій часу // Музичний світ Бориса Лятошинського : зб. матеріалів. Київ : Центрмузінформ, 1995. С. 26-29.

10.Пясковський І. Оновлення романтичних і постромантичних традицій в ладогармонічному мисленні Б. Лятошинського // Українське музикознавство. Київ, 1991. Вип. 26. С. $74-$ 93.

11.Самохвалов В. Черты музыкального мышления Б. Лятошинского. Киев : Музична Україна, 1970. 280 с.

12.Сокол А. Исполнительские ремарки, образ мира и музыкальный стиль. Одесса : Моряк, 2007. $276 \mathrm{c}$.

13.Степанюк О. Стешенко-Куфтіна Валентина Костянтинівна // Науковий вісник НМАУ ім. П. І. Чайковського. Вип. 101: Зі спадщини майстрів. Історія Київської консерваторії / ред.-упоряд. К. І. Шамаєва. Київ, 2013. С. 468-469.

14.Стешенко-Куфтина В. Из дневника. Письма Б. Н. Лятошинского к В. К. СтешенкоКуфтиной / розшифровка та підготовка до друку В. М. Воробйова та О.С. Степанюк // Науковий вісник НМАУ ім. П. І. Чайковського. Вип. 101: Зі спадщини майстрів. Історія Київської консерваторії / ред.-упоряд. К. І. Шамаєва. Київ, 2013. Вип. 101. С. 344-367.

15.Тарасова О. Артикуляционный комплекс в музыке : теоретический аспект // Традиції та новації у вищій архітектурно-художній освіті. Київ, 2008. Випуск 1, 2, 3. С. 124-127.

16.Харченко Є. Інтертекстуальність в українській музиці двадцятого століття : інтонація, жанр, стиль : дис. ... канд. мистецтвознавства спец. 17.00.03 Музичне мистецтво / Нац. муз. акад. України ім. П. І. Чайковського. Київ, 2011. 353 с.

17.Царевич I. Камерно-інструментальні ансамблі Б. Лятошинського, створені у 20-х роках // Українське музикознавство. Київ, 1972. Вип. 7. С. 103-118.

\section{REFERENCES:}

1. Belza, I. (Ed.) (1972), Piano works by Boris Lyatoshinsky : B. Lyatoshinsky. Sochineniya dla fortepiano [B. Lyatoshinsky. Piano works], Muzyka, Moscow, 132 p. [in Russian].

2. Davydov, N. (2013), “Aspects of performer's thinking”, Tavriyski studiyi. Mysteztvoznavstvo [Taurica Studies. Theory of Art], vol. 3, [in Russian], available at: http://nbuv.gov.ua/UJRN/tsm_2013_3_5 (accessed 01 feb 2018).

3. Klin, V. (1987), "Piano oeuvre and artistic style of B. N. Lyatoshinski", Boris Nikolayevich Lyatoshinsky, Muzychna Ukrayina, Kyiv, pp. 42-62 [in Russian].

4. Korykhalova, N. (1979), Interpretation of music: theoretical problems of performance and critical analysis of their research in the modern bourgeoise aesthetics, Muzyka, Leningrad, 208 p. [in Russian].

5. Lyatoshinsky, B. (2002), Epistolary heritage, vol. 1, Kyiv, 768 p. [in Russian, Ukrainian].

6. Malinkovskaya, A. (2005), Class of the main musical instrument: the art of piano intonation, VLADOS, Moscow, 381 p. [in Russian].

7. Martsenkivska, O. (2014), "General tendencies of romanticism in music and their manifestation in the piano oeuvre by B. Lyatoshinsky", Kyyivske muzykoznavstvo [Kyiv musicology], vol. 48, pp. 132-148 [in Ukrainian].

8. Moskalenko, V. (2012), Lectures on musical interpretation, Kyiv, 272 p. [in Russian]. 
9. Pidsukha, O. (1995), “On the problem of the B. Lyatoshinsky's stylistic searches in 1920 s in context of the contemporary european stylistic tendencies", Muzychny svit Borysa Lyatoshynskoho [Boris Lyatoshinsky's music world], Tsentrmuzinform, Kyiv, pp. 26-29 [in Ukrainian].

10.Pyaskovsky, I. (1991), "Renovation of the romantic and postromantic traditions in the harmonic thinking of B. Lyatoshinsky", Ukrayinske muzykoznavstvo [Ukrainian musicology], vol. 26, pp. 74-93 [in Ukrainian].

11.Samokhvalov, V. (1970), Features of the B. Lyatoshinsky's musical thinking, Muzychna Ukrayina, Kyiv, 280 p. [in Russian].

12.Sokol, A. (2007), Performer's directions, image of the world and music style, Moryak, Odessa, 276 p. [in Russian].

13.Stepanyuk, O. (2013), "Steshenko-Kuftina Valentyna Kostyantynivna", Naukovy visnyk NMAU im. P.I.Chaykovskoho [Scientific Messenger of the NMAU in the name of P.Tchaikovsky], vol. 101, pp. 468-469 [in Ukrainian].

14.Steshenko-Kuftina, V. (2013), "From the diary. Letters by B. N. Lyatoshinsky to V. K. Steshenko-Kuftina”, Naukovy visnyk NMAU im. P.I.Chaykovskoho [Scientific Messenger of the NMAU in the name of P.Tchaikovsky], vol. 101, pp. 344-367 [in Russian].

15.Tarasova, O. "Articulation complex in music: theoretical aspect", Tradytsiyi ta novatsiyi $\mathrm{u}$ vyshchiy arkhitekturno-khudozhniy osviti [Traditions and innovations in higher education in architecture and arts], vol. 1, 2, 3, pp. 124-127 [in Russian].

16. Kharchenko, Ye. (2011), Intertextuality in the Ukrainian music of the 20th century: intonation, genre, style, $\mathrm{PhD}$ diss. (music art), Institute of Art Studies, Folklore Studies and Ethnology named after M.T. Rylsky, 353 p. [in Ukrainian].

17.Tsarevych, I. (1972), "Instrumental chamber ensembles by B. Lyatoshinsky created in 1920s", Ukrayinske muzykoznavstvo [Ukrainian musicology], vol. 7, pp. 103-118 [in Ukrainian].

Стаття надійшла до редакиії 21.03.2018 p.

\section{OLEG BEZBORODKO}

https://orcid.org/0000-0002-7031-4078

National music academy of Ukraine named

after P. I. Tchaykovsky (Kyiv, Ukraine);

olegbezborodko@gmail.com

\section{The interaction of compositional and performing means of expressiveness in the Second Sonata-Ballade by Boris Lyatoshinsky}

Relevance of the study. Despite the division of the spheres of compositional and performing musical creativity the traditional generally accepted distinction between compositional and performing means of expressiveness is recognized by many researchers as ambiguous and conditional. The unprecedented actualization of the "secondary" performing means of expressiveness in the musical art of the twentieth century stipulates the urgency of applying this aspect of research to the study of the early piano pieces by the leading Ukrainian composer of the twentieth century Boris Lyatoshinsky. Main objective of the study is to highlight the interaction of compositional and performing means of expressiveness in the Second Sonata-Ballade by B. Lyatoshinsky. 
Methodology. A holistic musical-theoretical analysis is applied to determine the figurative content of a work, to reveal the features of form-building and the use of compositional means of expressiveness (the intonational structure of the basic elements of the form, the tonal-harmonic plan, the methods of development of the thematic material). Complex interpretation analysis is applied to study how performing means of expressiveness (tempo-rhythm, agogics, pedalization, dynamics) are used in their interaction with composer means of expressiveness.

Results and conclusions. In this work, the composer counts on the significant co-creative role of the interpreter. So, the definition of the tempo plan of the work is essential for the perception of the form, which ambivalence is evident already from the title of the work. A significant degree of metrorhythmic freedom is expected with accurate observance of rhythmic figures of a nervous, impulsive nature. It is necessary to use special dynamic and pedal techniques to identify impressionistic features of the B. Lyatoshinsky's piano texture.

Practical significance. The thourough understanding of the dialectics of interaction between compositional and performing means of expressiveness is necessary in order to achieve an adequate and convincing interpretation of this outstanding work of Ukrainian piano music.

Keywords: musical means of expressiveness, compositional means of expressiveness, performing means of expressiveness, interpretation, B. Lyatoshinsky's piano oeuvre.

\section{БЕЗБОРОДЬКО О.А.}

https://orcid.org/0000-0002-7031-4078

Национальная музыкальная академия Украины

имени П. И. Чайковского, Киев, Украина

olegbezborodko@gmail.com

\section{Взаимодействие композиторских и исполнительских средств выразительности во Второй сонате-балладе Бориса Лятошинского}

Актуальность исследования. Несмотря на разделение сфер композиторского и исполнительского музыкального творчества, традиционное общепринятое разграничение композиторских и исполнительских средств выразительности признается многими исследователями неоднозначным и условным. Беспрецедентная актуализация «вторичных» исполнительских средств выразительности в музыкальном искусстве XX столетия обуславливает актуальность приложения данного исследовательского аспекта к изучению ранних фортепианных произведений корифея украинской музыки XX века Бориса Лятошинского. Цель статьи заключается в освещении взаимодействия композиторских и исполнительских средств выразительности во Второй сонате-балладе Б. Лятошинского.

Методы исследования. Целостный музыкально-теоретический анализ применяется для определения образного содержания произведения, выявления особенностей формообразования и использования композиторских средств выразительности (интонационное строение основных элементов формы, тонально-гармо- 
нический план, приемы развития тематического материала). Комплексный интерпретационный анализ используется для исследования особенностей применения исполнительских средств выразительности (темпоритм, агогика, педализация, динамика) в их взаимодействии с композиторскими средствами выразительности.

Выводы. В данном произведении композитор рассчитывает на значительную сотворческую роль интерпретатора. Так, от определения темпового плана произведения зависит восприятие формы, амбивалентность которой заложена в названии произведения. Ожидается значительная степень метроритмической свободы при точном соблюдении ритмических фигур нервного, импульсивного характера. Необходимо применение особых динамических и педальных приемов для выявления импрессионистических черт фортепианного письма Б. Лятошинского. Практическое значение статьи заключается в необходимости понимания диалектики взаимодействия композиторских и исполнительских средств выразительности для достижения адекватной и убедительной интерпретации выдающегося произведения украинской фортепианной музыки.

Ключевые слова: музыкальные средства выразительности, композиторские средства выразительности, исполнительские средства выразительности, интерпретация, фортепианное творчество Б. Лятошинского. 